\title{
Vietnamese Commercial Banks in Global Integration Context: Opportunities, Challenges and Recommendations
}

\author{
Ha Thi Thuy Van ${ }^{1}$, Dam Bich $\mathrm{Ha}^{1}$ \& Hoang Thi Viet $\mathrm{Ha}^{2}$ \\ ${ }^{1}$ Department of Accounting-Auditing, Thuong mai University, Hanoi, Vietnam \\ ${ }^{2}$ Department of Accounting-Auditing, Hanoi University of Industry, Hanoi, Vietnam \\ Correspondence: Ha Thi Thuy Van, Thuong mai University, Ho Tung Mau Street, Cau Giay Dist, Hanoi, Vietnam.
}

Received: August 1, 2017

Accepted: August 19, 2017

Online Published: August 21, 2017

doi:10.5430/afr.v6n3p184

URL: https://doi.org/10.5430/afr.v6n3p184

\begin{abstract}
In the context of integration, Vietnam has held increasing attraction for investors in many fields including that of providing financial services from Vietnamese commercial banks. Therefore, the commercial banking system needs to be prepared for competition as the number of foreign banks investing in Vietnam is on the rise. In particular, with the implementation of the international commitments in the financial sector, the commercial banking system in Vietnam will have a lot of opportunities as well as challenges. The purpose of this study is to propose opportunities, challenges and some recommendations for sustainable development of the commercial banking system in Vietnam.
\end{abstract}

Keywords: Commercial bank, Integration, Opportunities, Challenges

\section{Introduction}

In recent years, Vietnam has been increasingly integrated into the regional and global economy, has signed Free Trade Agreement (FTA), Trans-Pacific Strategic Economic Partnership (TPP). At the same time, since the ASEAN Economic Community (AEC) was established at the end of 2015, regional banks have been able to set up wholly-owned subsidiaries in Vietnam in accordance with the World Trade Organization (WTO) commitments and by 2020, they will possibly be free for establishment in the country. Accordingly, in the banking sector, especially in the period of 2011 - 2015, the commercial banking system has proactively implemented many intensive and effective integration programs, has been putting in constant effort to strengthen its cooperation with international monetary and financial institutions and has been looking for and expanding its relationship with potential partners to further support both technically and financially for Vietnam. However, the effectiveness of international economic integration of Vietnam remains insignificant in reality. The innovation process in the country, especially the reform of institutions, has not kept pace with the schedule and level of international commitments. Strategies for addressing risks and shocks for deeper integration have not been formulated. The integration context requires Vietnamese commercial banks to actively participate in the integration process because the domestic market no longer maintains high levels of protection as before and the commercial banks will have more fierce competition not only on their home market but also on the global scale. The new context also requires the State Bank to actively adjust and create a favorable legal environment for credit institutions, develop appropriate policy frameworks for the banking system to ensure effective operation and timely resist possible external shocks. In order to build a reputable, competitive and secure banking system with the ability to mobilize all resources in society for effective investment, it is necessary to identify the right institutions. Assembly and challenges for Vietnamese commercial banks in the integration game.

\section{Objectivities and Methodologies}

The objective of this article is to study the commercial banking system of Vietnam in the context of integration. In particular, point to the opportunities of the commercial banking system in Vietnam in the context of Vietnam has been increasingly integrated into the regional and world economy. At the same time, also offer the opposite many challenges and difficulties. On that basis, the author proposes some recommendations for sustainable development of the commercial banking system in Vietnam. From there, it will come up with more realistic solutions for mobilizing investment capital for infrastructure development of Vietnam in the period of integration.

In order to complete this research, the author has applied some methods such as statistics and data and types of literature synthesis for comparison, analysis, assessment, performance of commercial banks.. Specifically, the research methods used by the author in this article are as follows: 
Firstly, Method of collecting data and information:

Secondary data collection method: The topic analyzes previous studies on commercial banks in several countries around the world, especially those of some countries in the world such as Asian countries, India, China, England, Chile... Besides, the author investigates scientific topics at all level, articles, speeches, some PhD theses, Master theses on this area from 2010 up to now.

Primary data collection method: The author conducts in-depth interviews. After obtaining information orientation, the data needs surveying and collecting. The author interviews a number of commercial banks such as staff of State commercial banks, $\mathrm{BIDV}, \mathrm{MB}, \mathrm{ABB}, \ldots$ on the issues related practically to capital mobilization and the main results obtained from the mobilization of these sectors in the period $2010-2015$.

Secondly, the method of synthesizing and processing information

- Secondary information and data are arranged according to each research content and divided into 3 groups:, Opportunities and challenges for Vietnamese commercial banks in the context of integration, and Some recommendation.

- Methods of analysing information: All primary data collected from in-depth interviews will be analyzed by comparative analysis and expert method.

\section{Opportunities and Challenges for Vietnamese Commercial Banks in the Context of Integration}

\subsection{Open up Many New Opportunities}

Firstly, the formation of new banking business models. The opening up and integration in the banking sector in addition to allowing domestic and foreign commercial banks to run business, compete and grow in a level playing field, equality. At the same time, create favorable conditions for domestic commercial banks to penetrate the international market and expand business.

By the end of 2015, the commercial banking system of Vietnam has had a strong and diversified development, with the form of state commercial banks, joint stock commercial banks, joint venture banks and foreign bank branches (Table 1). This is also a prerequisite for Vietnamese commercial banks to develop and integrate

Table 1. The systems of Vietnamese commercial banks

\begin{tabular}{llllll}
\hline Banks & $\mathbf{2 0 1 2}$ & $\mathbf{2 0 1 3}$ & $\mathbf{2 0 1 4}$ & $\mathbf{2 0 1 5}$ & $\mathbf{2 0 1 6}$ \\
\hline State commercial banks & 2 & 1 & 1 & 1 & 4 \\
Joint-stock commercial bank & 38 & 38 & 38 & 37 & 31 \\
$\begin{array}{l}\text { Commercial joint venture bank } \\
\text { Commercial banks with 100\% foreign }\end{array}$ & 5 & 4 & 4 & 4 & 3 \\
capital & 5 & & 5 & 5 & 5 \\
\hline
\end{tabular}

(Source: aggregated data of the State Bank of Vietnam over the years)

Secondly, broaden the reach of foreign markets. International economic integration opens up a market opportunity for foreign commercial banks to Vietnamese commercial banks. Competition, but also increase the health and safety of the entire system of Vietnamese commercial banks have the opportunity to access capital, technology, experience and management level of the commercial banks in the world.

According to the content of the finalized negotiations in the financial services sector, a TPP service provider can provide financial services in other TPP markets if domestic companies operate. In this market is allowed to provide that service. In the period $2011-2015$, commercial banks in the country are prepared to catch up quite well this opportunity. Commercial banks (such as BIDV, VCB, Vietinbank) have pioneered the export of banking, securities and insurance services to foreign markets. To be proactive and cautious in approaching and exploring the markets of developed countries such as the United States, Germany and Russia to penetrate ASEAN countries' markets such as Laos, Cambodia and Myanmar; Next is the representative office, branch. Up to now, there are more than 20 branches and representative offices of Vietnamese commercial banks in foreign countries. However, the promotion of offshore investment by Vietnamese commercial banks is also facing the political, cultural and legal risks of host countries. The government in accessing information and promoting investment to reduce national risk in the field of banking and finance. 
By the end of 2015, commercial banks in Vietnam have 11 investment projects to establish branches / joint venture banks abroad (Table 2).

Table 2. Banks / branches of Vietnamese commercial banks in foreign countries

\begin{tabular}{|c|c|c|c|c|c|}
\hline Date range & Bank & $\begin{array}{l}\text { Receiving country } \\
\text { invest }\end{array}$ & $\begin{array}{l}\text { Total estimated } \\
\text { capital (USD) }\end{array}$ & $\begin{array}{l}\text { Total Vietnamese } \\
\text { Capital (USD) }\end{array}$ & $\begin{array}{l}\text { Profit before tax in } \\
2015 \\
\text { (million dollars) }\end{array}$ \\
\hline \multirow[t]{2}{*}{$08 / 02 / 2012$} & & Laos & 70.000 .000 & 45.500 .000 & 15.2 \\
\hline & BIDV & & & & \\
\hline $14 / 08 / 2009$ & & Campuchia & 70.000 .000 & 70.000 .000 & - \\
\hline $10 / 03 / 2010$ & Agribank & Campuchia & 39.000 .000 & 39.000 .000 & - \\
\hline $07 / 12 / 2010$ & MB & Laos & 12.000 .000 & 12.000 .000 & 1.3 \\
\hline $07 / 12 / 2011$ & & Campuchia & 39.000 .000 & 39.000 .000 & - \\
\hline \multirow[t]{2}{*}{$18 / 08 / 2011$} & & Campuchia & 38.000 .000 & 38.000 .000 & 1.7 \\
\hline & Sacombank & & & & \\
\hline $20 / 12 / 2012$ & & Laos & 38.000 .000 & 38.000 .000 & 4.1 \\
\hline $19 / 10 / 2011$ & & Campuchia & 39.000 .000 & 39.000 .000 & 2 \\
\hline $14 / 05 / 2012$ & SHB & Laos & 13.000 .000 & 13.000 .000 & - \\
\hline \multirow[t]{2}{*}{$19 / 10 / 2011$} & & Laos & 22.000 .000 & 22.000 .000 & - \\
\hline & Vietinbank & & & & \\
\hline $28 / 06 / 2012$ & & Germany & 65.500 .000 & 65.500 .000 & - \\
\hline
\end{tabular}

(Source: Department of Foreign Trade - Ministry of Planning and Investment, Annual report of banks in 2015)

Thirdly, Technology transfer, modern banking management techniques. At most joint-stock commercial banks with foreign ownership of over 5\%, foreign experts are in charge of such important positions as Techcombank, VIB. The opportunity to work with experts, senior managers in the bank will help transfer technology, skills and good management skills to Vietnamese bank managers. In addition, many domestic commercial banks have hired foreign consultants to provide consultancy packages focusing on: Strategic Planning, Business Planning, Risk Management, Human Resource Management, Evaluate service quality. It can be said that this is the initiative of commercial banks in anticipation of business opportunities in the integration environment to find common voice with investors and foreign partners on the way, compete for mutual development.

In addition, many commercial banks have applied modern software systems to manage the banking system such as core-banking system, customer management system CRM constantly improve service quality. Compared to the time before equitization, state-owned commercial banks, including VCB, BIDV and Vietinbank, had a clear change in both quality and quantity.

Fourthly, integration will create motivation to promote innovation and enhance transparency, publicity, governance and self-responsibility of the system of Vietnamese commercial banks in accordance with international standards. Thereby, improve the operating efficiency in the field of currency and banking. As the rate of foreign ownership in 
commercial banks increases, it means that SOCBs must standardize governance, accounting and finance in line with international practice, Standards of transparency, publicity.

Most commercial banks, when listed on the stock market, had to convert their accounting systems into international standards (IFRS), in addition to the Vietnamese Accounting Standards (VAS). This is indispensable when commercial banks have a need to list on the international market. Accordingly, a number of large commercial banks have also hired valuation organizations, international ratings to credit rating. Public ratings by international organizations will open up opportunities to penetrate international markets in the context of integration of Vietnamese commercial banks.

Fifthly, integration requires a better regulatory environment to implement international commitments, create an attractive investment climate, and encourage capital inflows through direct and direct investment. Indirect foreign indirect investment, creating opportunities for commercial banks to lend and mobilize larger capital

At the same time, it opens up opportunities for commercial banks to seek foreign strategic shareholders in order to overcome the limitations on financial capacity, governance and competitiveness to improve service quality, business performance. In the last 10 years, many Vietnamese banks have selected large foreign financial institutions as their strategic shareholders (Table 3).

Table 3. Strategic shareholders of several Vietnamese commercial banks (As of 2016)

\begin{tabular}{|c|c|c|c|}
\hline Bank & $\begin{array}{l}\text { Foreign } \\
\text { shareholder }\end{array}$ & Initial investment time & $\begin{array}{l}\text { Share } \\
\text { ownership } \\
\text { ratio }\end{array}$ \\
\hline ABBank & Maybank & $03 / 2008$ & $20 \%$ \\
\hline ACBank & Standard Chartered & $06 / 2005$ & $15 \%$ \\
\hline Techcombank & HSBC & $12 / 2005$ & $20 \%$ \\
\hline Eximbank & SMBC & $11 / 2007$ & $15 \%$ \\
\hline Sacombank & Macquarie Capital & $11 / 2011$ & $14 \%$ \\
\hline Vietcombank & Mizuho & 09/2011 & $15 \%$ \\
\hline Southern Bank & UOB & $05 / 2007$ & $15 \%$ \\
\hline
\end{tabular}

(Source: Website of the above banks)

In the context of the inevitable development trend of the Vietnamese financial market, in the context of the restructuring and integration of the global financial environment, the potential for the formation and development of financial institutions in the form of investment banking Comprehensive is an objective reality. The problem is that managers, market supervisors and policymakers need to study early to create a legal corridor for these new financial institutions, thus creating a level playing field, Competition and sustainable development in the current deepening integration.

\subsection{No Less Challenge}

Besides the opportunities from international integration, the banking system in Vietnam faces many internal difficulties in the economy as well as the internal of each bank, the institution of the banking system is still many. Inadequate, inadequate reform requirements and integration roadmap are major challenges for Vietnamese commercial banks in the integration process.

Firstly, integration also brought fierce competition and fierce in the banking market in Vietnam. Foreign commercial banks currently only hold a minority market share in Vietnam's banking and finance market, but will have a near-comprehensive advantage in the future, when the restriction of the Vietnamese State to Foreign commercial banks are loosened gradually. It is noteworthy that, in previous years, foreign banks appeared in Vietnam mainly in countries and territories with much investment in Vietnam, such as Japan, Korea, China, Taiwan ... Recently, Asian banks have appeared more and more, such as DBS Bank (Singapore), Maybank (Malaysia) ... It seems that credit institutions in the region are ready to welcome opportunities from AEC.

Secondly, the share of foreign ownership in joint stock commercial banks increased. For commercial banks, opening up the domestic market means increasing foreign ownership. With the permitted ceiling of $30 \%$, Vietnamese commercial banks, Vietinbank now has the highest foreign ownership ratio of over $28 \%$. 
Among joint-stock commercial banks, the proportion of foreign ownership generally tends to increase in large and medium banks such as ACB, EIB, TCB, VIB, VPB, from 20-30\%. In particular, ACB has a 30\% ceiling rate of foreign ownership in the 2013-2016 period. An Binh Bank, although a small bank, has consulted with the International Finance Corporation (IFC, World Bank Group) since 2013, has increased its foreign ownership from 0 to $20 \%$ in 2012-2013 and 30\% in 2014 to 2016. It was thanks to the increase in foreign ownership that ABB took the initiative to restructure, "escape" the list of weak banks forced to restructure passive.

In addition, two banks with a sharp increase in foreign ownership in the restructuring period 2013-2016 are Saigon Trade and Industry Corp (SHB). This reaffirms the positive impact of the increase in foreign ownership, but poses a challenge for joint stock commercial banks, especially small banks, if not to hold. Proprietary rights will be transferred to foreign investors.

Thirdly, the market share of local banks declined. In the period 2011 - 2016, the market share of credit and capital mobilization of commercial banks compared to foreign banks tends to decrease markedly. Although large state-owned commercial banks dominate the credit market, they tend to decline. Moreover, in the capital mobilization market, state-owned commercial banks have been weak when the market share is lower than that of joint stock commercial banks because the joint stock commercial banks are more competitive. The deposit interest rate should account for a larger market share.

In fact, in both the credit and capital markets of commercial banks in Hanoi, the market share of foreign banks is on the rise. As soon as WTO commitments enter into force, state-owned banks are entitled to mobilize capital from the population, providing personal lending services, and being a Vietnamese institution, which is Rich land for foreign banks to exploit the strength of service quality outperform the domestic commercial banks. This is evident when in the credit market, foreign banks account for 10-15\% of the market share with diverse products, rich and professional service quality has attracted Vietnamese customers. The market share of capital mobilization, although more modest, accounts for only 5-7\% of market share, but foreign banks are also attractive to middle-income and middle-income customers. Average and high, then the cost of mobilizing 1 dong of foreign banks will be relatively low relative to the domestic commercial banks.

Fourthly, pressure to improve service quality, product diversification, investment in modern technology. It is from the sharp decline in market share of commercial banks in Vietnam, it can be seen that improving the quality of services of domestic banks is an indispensable requirement to improve competitiveness. In the context of integration. It is undeniable that foreign banks are becoming more attractive than local banks. As Vietnamese become more educated and have higher incomes, they are more likely to look to foreign banks. Better service providers. The segment of high-income and middle-income customers, intellectual customers will gradually shift to transactions with the SBV, then, of course, if the domestic banks do not invest, renovate strongly. High technology and quality, diversified products and services will inevitably "lost on the ground".

In terms of technology infrastructure and payment systems, Vietnamese banks are far from the requirements of integration. Although local banks are making every effort to upgrade their technology systems through modernization projects, their financial capacity is limited so they can not meet the requirements in a short period of time. Over time, The State bank of Vietnam has asked local banks to review their technology governance capabilities over Basel II through the Data Gap tool. As a result, local banks only meet about $40-60 \%$ of Basel II requirements. That shows that technology governance is a great challenge to the pressure of international integration of the commercial banking system in Vietnam.

Fifthly, integration requires Vietnamese commercial banks to have a human resource that is not only highly specialized in banking but also must understand the international trade law, be fully equipped with knowledge and techniques. Research, analysis, evaluation and forecasting in line with international standards and models, while human resources of Vietnamese commercial banks are very weak in knowledge and skills.

Unlike many service sectors, the human resources of the banking sector must be of exceptionally high quality, including skilled workers, good foreign languages, and scientific and technical progress. High technology and good morals. Among them, financial professionals must be strategic visionaries, taking decisive action and principles as a "leader," especially when dealing with complex business events. Moreover, high quality human resources are important conditions to ensure healthy, efficient and competitive development; It is also a key factor for Vietnam to become a regional and international financial center. However, the banking sector in Vietnam is seriously scarce labor resources of high quality, especially financial professionals with international qualifications. Hence, in order to meet the rigorous requirements of integration, the banking system of Vietnam should enhance the training of human 
resources of high quality, meeting international standards, knowledge of practices, business practices and international risks.

Sixthly, opening up the banking and finance market in the process of integration will inevitably lead to the risk of being overtaken by domestic commercial banks and the consequences arising from the problem of cross-ownership. With the strength of finance, technology and human resources, foreign banks often penetrate and develop new markets by buying shares of Vietnamese commercial banks and become strategic shareholders, seeking to acquire them. Acquire these banks, or carry out M \& A banking deals. This is the way to help foreign banks get into the financial market in Vietnam more quickly. In this case, if Vietnamese banks do not have "sanity" in managing and controlling capital, then the probability of acquisition is unavoidable. On the other hand, integration with foreign roommaps in the financial market of Vietnam will create momentum and opportunities for cross-border investment between commercial banks or between commercial banks. With large corporations, leading to the problem of cross-share ownership in many forms. This is a big challenge nowadays, is the biggest barrier to manipulate and affect the entire banking system in the process of restructuring.

\section{Some Recommendation}

Before the opportunities and challenges that the context of international integration bring, the commercial banks in Vietnam need to overcome the internal challenges, continue to restructure, enhance competitiveness, expand the scope activity. In order to achieve that goal, the author would like to propose 2 groups of recommended solutions to be implemented as follows:

\subsection{Macro Solutions}

Firstly, conduct inspection, assessment, classification and classification of commercial banks based on criteria and criteria for good and safe banking evaluation. The smallest group of banks, failing to meet the rating criteria, will be forced to cease operations, merge with banks capable of restoration and good financial status are encouraged to merge. To form a new bank of a larger scale, to operate more efficiently.

Secondly, to amend, supplement and perfect the legal corridor: At all levels of management, a legal corridor of publicity, transparency and fairness should be developed to facilitate equal commercial banks. In competition, ensure system security, while improving public confidence in the banking system. At the same time, it is necessary to have a coordinated coordination between the State Bank of Vietnam and related ministries and agencies in the issuance of legal documents, as well as the control over the handling of cross ownership issues. The cross-treatment of cross-compliance should be to prevent deliberate infringement, to eliminate the benefits of cross-ownership of individuals and organizations.

Thirdly, enhance the role of direction, management, supervision of the State Bank and the Government. The supervision of the State Bank and the Government for commercial banks must be carried out regularly, continuously and flexibly and to assist the organizations to be monitored, to ensure the systematic and effective coordination of policies. And international cooperation in financial supervision so that banks operate safely and effectively, avoiding unfair competition. At the same time, effective coordination of the restructuring of the commercial bank system with strong development of financial markets, securities, insurance and investment funds in accordance with international standards to meet capital needs for the fourth economy, continued active international integration in the field of monetary, credit and banking. This integration process needs to be calculated in a way that is consistent with the capacity of commercial banks and the ability of management and supervision of state management agencies.

\subsection{Solutions from Vietnamese Commercial Banks}

\section{Firstly, need to strengthen financial capacity}

The commercial banks should be active in the main aspects, such as equity, asset quality, liquidity, profitability. In order to ensure this, Vietnamese commercial banks must first build a roadmap and step by step increase their charter capital by: issuing shares to domestic and foreign investors, voluntarily merging, To merge, improve capital adequacy ratio according to Basel II standards. Increasing charter capital is a prerequisite for achieving economies of scale, meeting the ever-widening and large financial potential needed to cope with the uncertainties of the international business environment. .

\section{Secondly, enhance the capacity of executive management}

In order to improve the governance capacity, commercial banks should clearly define the rights and responsibilities of boards and head office centers, as well as strengthen the coordination between these boards and their branches, To set up an early warning system and develop a system of tools and software programs for market risk management 
and operation in line with international standards and practices, enhancing the quality of the project work. Market research, management and market research for the development of non-credit services, and good policies for good managers to retain and attract talents.

Thirdly, improve the quality of human resources in the direction of improving professional level, creativity, ability to communicate, professional working style.

In order to do this, it is necessary to set specific criteria at the recruitment stage, and to combine training and regular retraining of staff. For managers at all levels should have the potential should have plans to train, practice, exchange staff between reputable foreign banks operating in and outside the country. At the same time, research on the application of modern information technology in the effective management of human resource utilization, employee evaluation in accordance with professional ethics standards, and efficiency is the main measure To use talents and talents to effectively use human resources in each stage of development; To attach importance to the training and retraining of human resources in a comprehensive manner, step by step raising the quality of human resources in a uniform and steady manner in the direction of both intensive and comprehensive, highly competitive and always oriented. To customers; Have a policy to attract talents through compensation.

Fourth, continue to innovate and modernize banking technology.

In recent years, although the application of banking technology of commercial banks has gone a step further, compared to commercial banks of advanced countries in the world, the technology used in commercial banks is quite backward. Therefore, commercial banks must have specific plans and conduct technological innovations in order to create highly competitive products and services and the ability to maintain good information to enhance their competitiveness.

Fifthly, reorganize the network in a scientific way.

For a long time, commercial banks have been constantly expanding their networks, without paying much attention to their effectiveness, management capacity, and so on., Large urban areas), in some places (rural, remote). So in the coming time, commercial banks need to have specific solutions to restructure the network such as: merging, dissolving, changing management personnel, but minimizing disturbance, psychological puzzling for staff.

\section{Conclusion}

It can be said that international integration is an indispensable development trend of all economies, opening up many opportunities for the development of nations, organizations, enterprises and banks; But it also poses a lot of challenges and pressures for nations, organizations and banks to face. Therefore, the process of international economic integration will create greater pressure for business activities of Vietnamese commercial banks while the potential advantage will belong to foreign commercial banks. The competition not only takes place overseas but also takes place in the domestic market, where Vietnamese commercial banks still have many advantages if they take advantage of those advantages. To be able to master the advantages, take advantage of opportunities and increase competitiveness, Vietnamese commercial banks need to know their position, equip themselves with a certain knowledge of integration, must assess their competitiveness. Its based on the criteria mentioned. At the same time, identifying clearly the opportunities and challenges of integration will help regulators, businesses, researchers, policymakers be active, cautious and confident. With the challenge and opportunity, the ultimate goal is to enhance the competitiveness of organizations, enterprises, banks and countries in the international market.

\section{References}

ADB, (2010). Methodology for Impact Assessment of Free Trade Agreement.

Assoc., PhD Nguyen Thi Quy. Competitiveness of Commercial Banks in the Integration Trends - Political Theory Publishing House-page 78

Bao Tran, Bernice Ong, Scott Weldon. (2015). Vietnam Banking Industry Report, Publish by Duxton Asset Managenment. 1/23/2015.

https: //ustr.gov/about-us/policy-office/press-ofice/press-releases/2015/otober/summary-trans-pacific-partnership

Institute for Economic and Policy Research, "Report on the impact of TPP on the Vietnamese economy" (2015).

Le Thi Thuy Van \& his team, (2015), Impact Assessment of Free Trade Agreements, Vietnam Economic and Financial Review, 2 - 2015.

Morgan Stanley. (2015). ASEAN financials: 2015 Outlook. 
Nguyen Cam Nhung. (2013). Thailand's Financial Integration in AEC. Vietnam's Socio-Economic Development. A Social Science Review. No 75; P49-60. October 2013.

Nguyen Hong Son, Trinh Thi Mai Hoa, Tran Thi Thanh Tu. (2014). Sustainable development of the banking system in Vietnam before the restructuring trend, National Political Publishing House.

PGS. TS. Pham Duy Nghia. (2013). Transpacific Partnership Agreement - TPP: Opportunities for Vietnam, Publisher of the Times.

Pham Huy Hung. (2015). Vietinbank after six years of WTO accession - issues.

Proceedings of the "Transpacific Economic Partnership Agreement (TPP) - meaning and impact on the Vietnamese economy", March 2013.

State Bank of Viet Nam. (2015). ASEAN Financial-Financial Integration Report.

Trans-Pacific Strategic Economic Partnership Agreement. (2005). VCCI (2013), "Summary of the 16th negotiation of the Trans-Pacific Partnership (TPP) negotiation" at http://tiemtamwto.vn/tpp/lich-su-hinh-thanhva-dien-bien-dam -phan-tpp

Website of the State Bank of Vietnam: htpp: //www.sbv.gov.vn 